\title{
Description of Loricyphes froehlichi, a new genus and species of Leptohyphidae (Ephemeroptera) from São Paulo, Brazil
}

\author{
Carlos Molineri $^{1 *}$ and Rodolfo Mariano ${ }^{2}$ \\ 1 Instituto de Biodiversidad Neotropical - CONICET (National Council of Scientific Research), National University of Tucumán, \\ Horco Molle (CP4107), Argentina \\ 2 Departamento de Ciências Biológicas (DCB), Universidade Estadual de Santa Cruz (UESC), Brazil, Km 16 rod. Ilhéus-Itabuna \\ CEP 45650-000, Ilhéus, Bahia
}

Received 5 June 2015; Accepted 27 October 2015

\begin{abstract}
Loricyphes froehlichi gen. et sp. nov. is described and illustrated from nymphs, subimago and eggs. Diagnostic characters include, in the nymph: head, thorax and abdomen with very large and pointed tubercles; maxillary palp absent; femora very long and slender, ratio length/maximum width $=5$; forefemur without transverse row of setae at dorsum and with few chalazae; tarsal claws with 12-17 marginal denticles, submarginal denticles absent; abdominal segments II-VII very wide and laterally expanded forming a shallow cavity for the dorsal-positioned gills; and in the egg: conic in shape, with one pole truncated and the other acute, polar capsule apparently absent, chorionic plates longitudinally arranged between longitudinal elevated ridges, adhesive filaments absent. The new genus is superficially similar to Coryphorus (Coryphoridae) but presents synapomorphies of Leptohyphidae, and it is probably related to Tricorythodes based on gill morphology.
\end{abstract}

Key words: Pannota / mayfly / neotropics / Tricorythodes / Coryphorus

\section{Introduction}

The knowledge of the family Leptohyphidae (Ephemeroptera) has been continuously growing in the last years, with many revisionary works and species descriptions (e.g., Wiersema and McCafferty, 2000; Molineri, 2006; Dias et al., 2007; Baumgardner and McCafferty, 2010). In South America 12 genera are recognized (Domínguez et al., 2006): Allenhyphes Hofmann and Sartori, Amanahyphes Salles and Molineri, Haplohyphes Allen, Leptohyphes Eaton, Leptohyphodes Ulmer, Lumahyphes Molineri, Macunahyphes Dias et al., Traverhyphes Molineri, Tricorythodes Ulmer (in the broad sense, including Asioplax Wiersema and McCafferty and Cabecar Baumgardner), Tricorythopsis Traver, Vacupernius Wiersema and McCafferty, and Yaurina Molineri.

In the present paper we describe a distinctive new genus and species based on nymphs, male subimago and eggs, showing a unique morphology in the group. The presence of dorsal spine-like tubercles on head, thorax and abdomen (simultaneously) is rare in the family, and was recently reported for a group of species in Leptohyphes (Nascimento et al., 2014). More common is the presence

\footnotetext{
*Corresponding author: carlosmolineri@gmail.com
}

of tubercles on individual tagma (e.g., on thorax or abdomen in some Tricorythodes, Molineri, 2002). The new genus described here shows a superficial resemblance to Coryphorus Peters, the sister group of Leptohyphidae (Molineri et al., 2002). The aim of this work is to describe and illustrate a new genus and species of Leptohyphidae: Loricyphes froehlichi.

\section{Material and methods}

Canada balsam was used for mounting dissected parts on microscope slides. All the material is preserved in ethyl alcohol $96 \%$. Gill formula refers to the number of lamellae present on each abdominal gill. Terms used in descriptions are from Molineri (2006). Photographs were taken using a NIKON SMZ-10 stereomicroscope, with a Nikon D5000 digital camera. Drawings were done with a camera lucida attached to the stereomicroscope. For scanning electron photography, the eggs were dehydrated in a graded ethanol series, dried, sputter coated with gold and observed with a JEOL $35 \mathrm{CF}$.

Depositories: Museu de Zoologia da Universidade Estadual de Santa Cruz (MZUESC), Ilhéus, Bahia, Brazil; Instituto de Biodiversidad Neotropical (IBN), Tucumán, Argentina. 


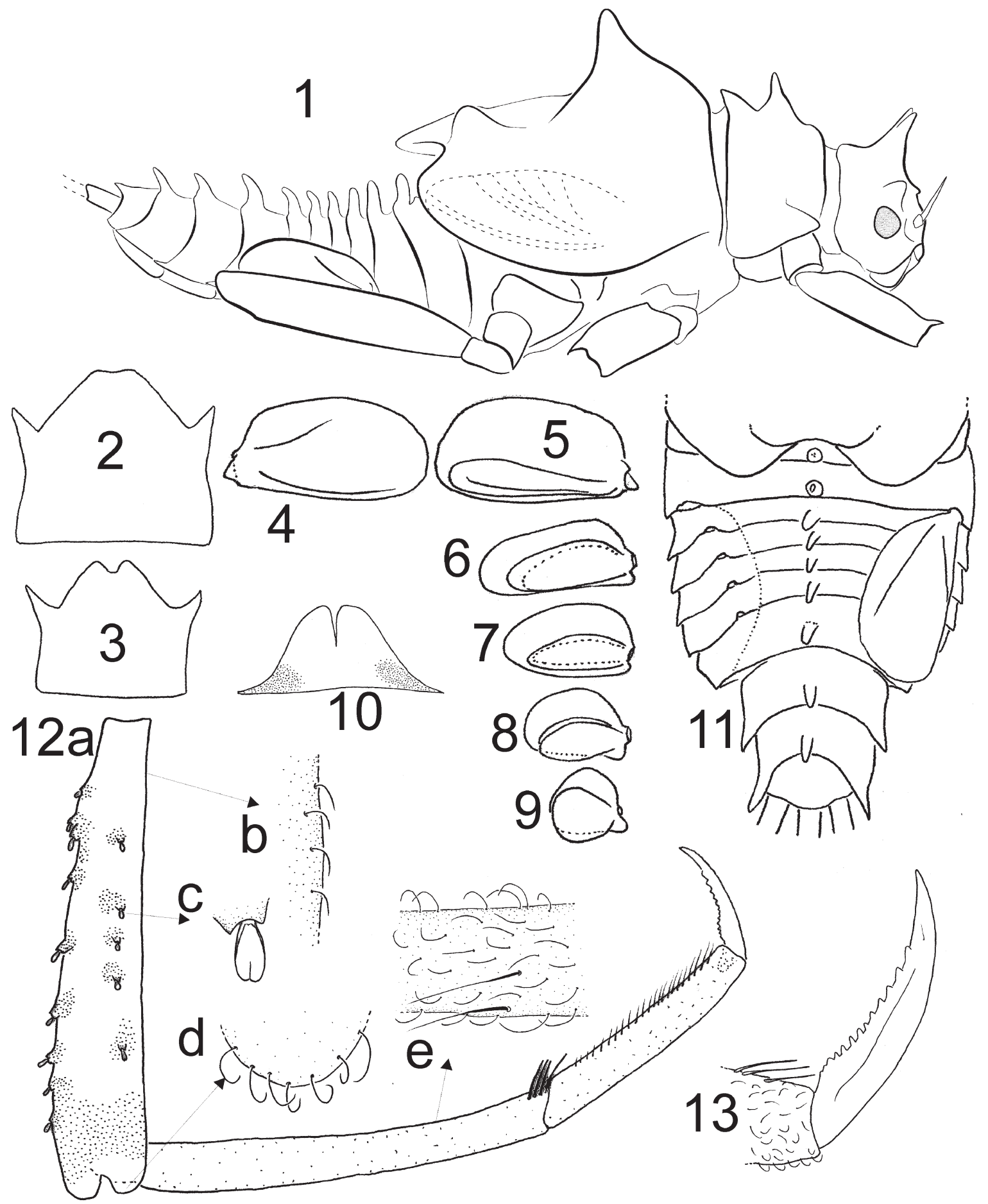

Figs. 1-13. Nymph: 1: general lateral view; 2: female sternum IX; 3: male sternum IX; 4: opercular gill, d.v.; 5: same, v.v.; 6: gill III, v.v.; 7: gill IV, v.v.; 8: gill V, vv.; 9: gill VI, v.v.; 10: penes of pharate subimago;11: abdomen, d.v.; 12: (a, foreleg with details; b, curved microsetae at margin; c, chalaza; d, femoral apex; e, setation on tibia); 13: foretarsal claw.

Loricyphes gen. nov. (Figs. 1-26)

Type-species: L. froehlichi sp. nov.

Diagnosis. Nymphs: (1) with a bifid tubercle on meson of head, and pointed ocellar tubercles (Figs. 1 and 21); (2) pronotum with two pointed tubercles on medial line (Figs. 1 and 22); (3) mesonotum with a large pointed tubercle anteriorly and a blunt smaller tubercle between wingpads (Figs. 1 and 22); (4) hind wingpads absent in both sexes; (5) maxillary palp absent (Fig. 14); (6) legs long and slender, ratio length/maximum width of forefemora $=5$ (Figs. 12, 19, 20 and 24); (7) transversal row of setae on dorsum of forefemora absent, with marginal and mediolongitudinal row of stout blunt setae on very elevated sockets (Figs. 12, 19 and 20); 


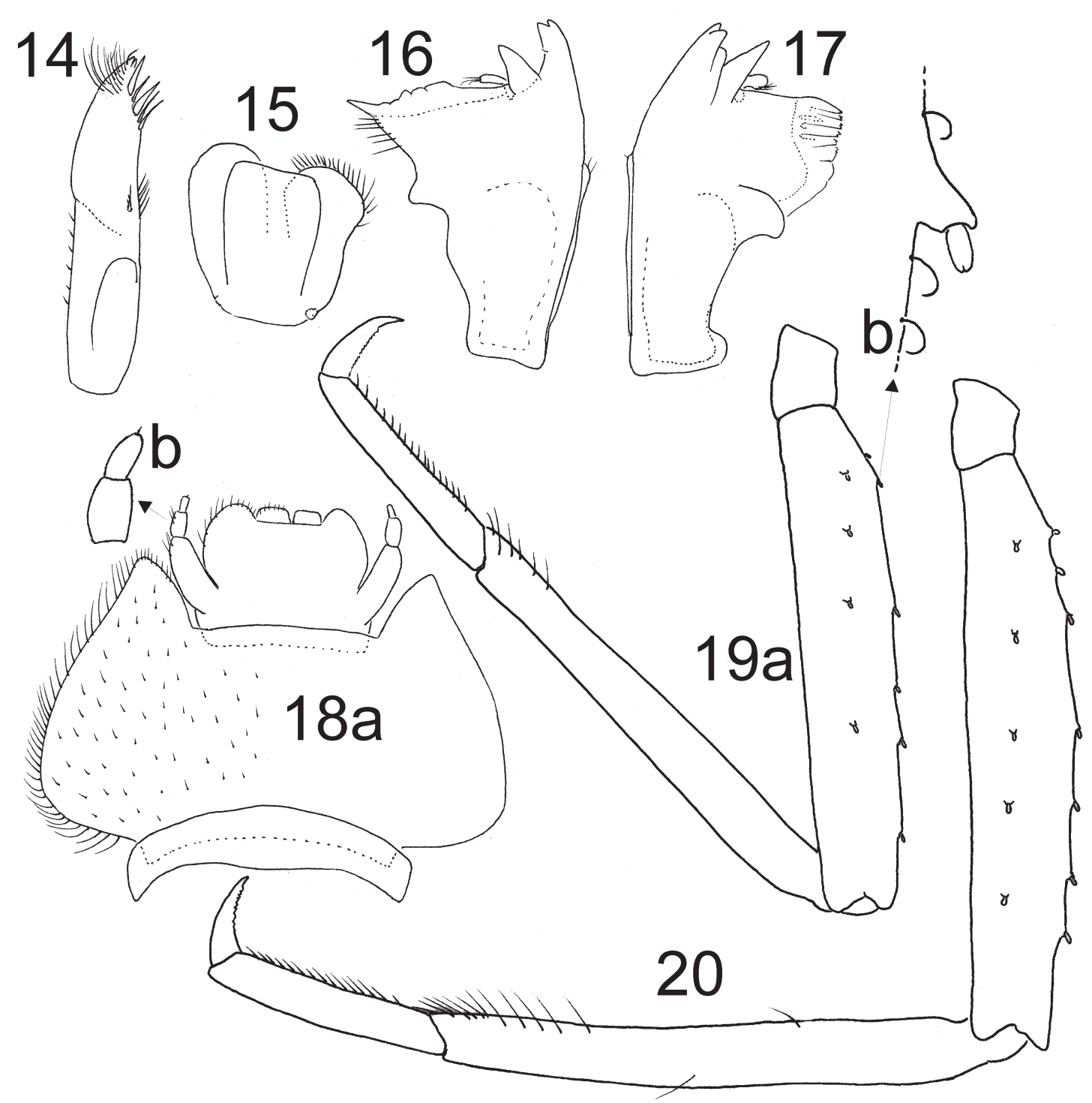

Figs. 14-20. Nymph: 14: maxilla, v.v.; 15: hypopharynx, v.v.; 16: right mandible, d.v.; 17: left mandible, d.v.; 18a: labium, v.v., 18b, detail of palp (setae on prementum and right side of submentum omitted); 19: (a, middle leg; b, details of chalaza); 20: hind leg.

(8) tarsal claws with 12-17 marginal denticles and without submarginal denticles (Fig. 13); (9) operculate gills subquadrate to subovate, brownish, darker at basal half (Figs. 4, 5, 24); (10) gill formula 2/3/3/3/2 (Figs. 5-9); (11) abdominal segments II-VII wide, lateral flanges on abdominal segments III-VII forming a concavity were gills lie, posterolateral spines present on segments I-IX (Figs. 11, 22 and 23). Eggs: (1) conic in shape, polar cap and adhesive filaments apparently absent (Figs. 25 and 26); and (2) chorionic plates ordered in longitudinal rows and intercalated with elevated ridges (Figs. 25 and 26).

\section{Description}

Subimago: (structures visible in a pair of ready to molt nymphs of both sexes). Penes pyramidal, with thin distal notch and with anterobasal area orangish (Fig. 10). Forceps unknown. Femora with small spines where chalazae were present. Hind wings absent.
Egg: length $(N=3), 156-158 \mu$; maximum width, 83-86 $\mu$. Conic, with abruptly truncated and wide pole, becoming thinner toward opposite pole (Figs. 25 and 26). The presence of polar cap is probable in the truncated pole, but it was not observed in the very few available eggs. Area around truncated pole is smooth, but on the rest of egg with longitudinal ridges alternating with rows of crescent-shaped chorionic plates (Figs. 25 and 26).

Mature nymph: length (mm). Male: body, 3.8; terminal filament, 1.8; cercus, 2.1. Female: body, 5.3; caudal filaments broken off and lost. Body cuticle very hardened, spines present in all tagma. Head (Figs. 1, 21 and 22) with large dorsal tubercle, bifid at the apex, between compound eyes; smaller "ocellar" tubercles on lateral ocelli. With shallow groove present on genae, near outer lateral margin of antennal base; and additional median groove anterior to large tubercle. Mouthparts: labrum with broad 


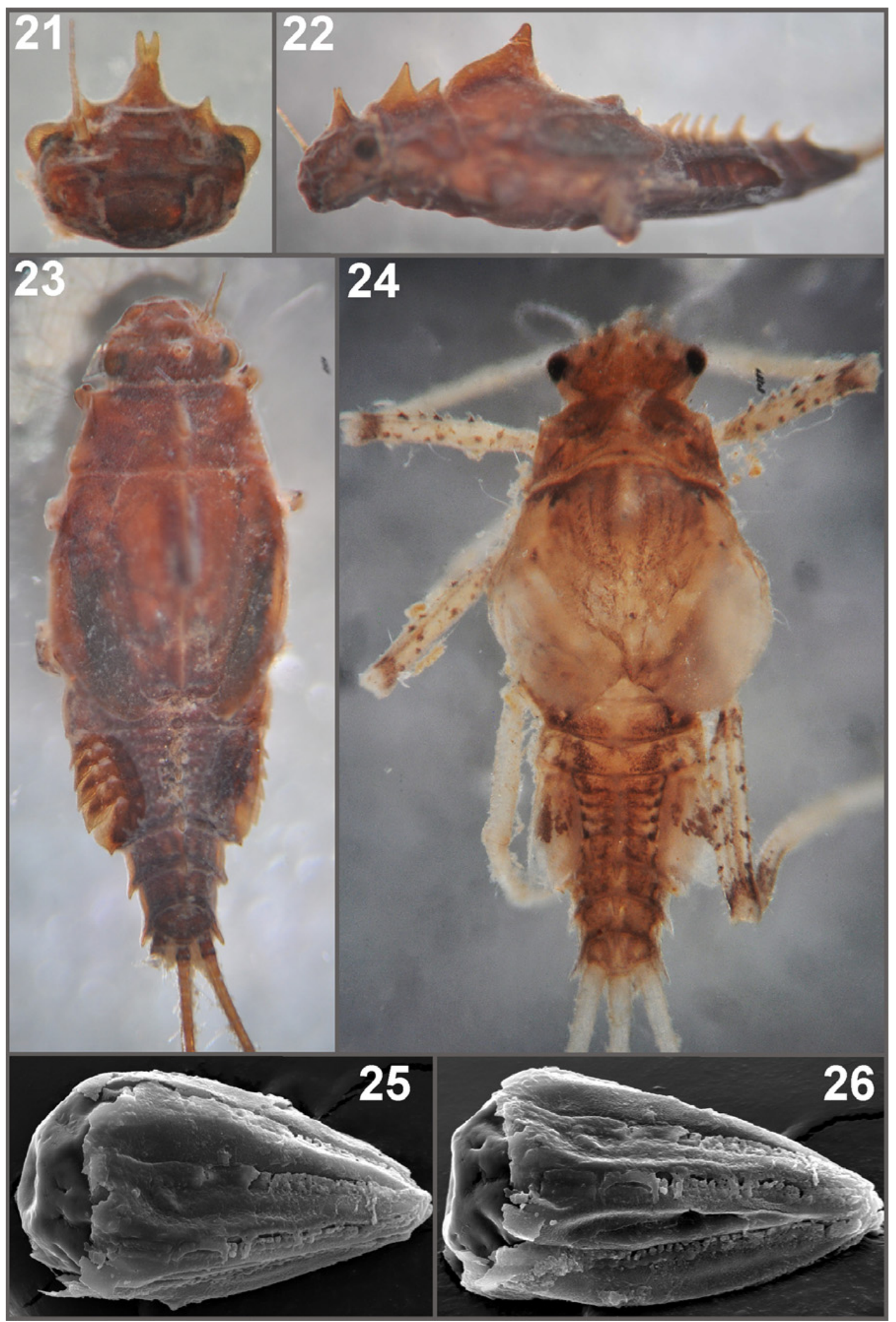

Figs. 21-26. Nymph: 21: female head, frontal view; 22: female, 1.v.; 23: female, d.v.; 24: male, d.v. Eggs (scanning electron microscopy): 25-26: general view.

anteromedian emargination (Fig. 21), short setae present mainly along fore margin; hypopharynx stout with rounded linguae (Fig. 15); maxilla (Fig. 14) without palpus, inner margin of stripes with longitudinal row of six setae, and a larger ventral pectinate seta; mandibles stout with slightly protruding ridge on outer margin 
(Figs. 16 and 17); labium with well-developed and pointed anterolateral projections on submentum (Fig. 18), labial palp three-segmented with small apical seta, segments decreasing in size distally as in Fig. 18(a) and (b). Thorax (Figs. 1 and 22-24). Pronotum with mediolongitudinal crest forming two large pointed tubercles, one median and other near posterior margin; anterolateral corners projected and pointed (Fig. 1). Mesonotum with very large anteromedian tubercle; rounded median protuberance present at apex between the wingpads. Metanotum small, not visible in mature nymphs, hidden below mesonotum. Legs (Figs. 12, 19 and 20). All legs are similar, long and slender, with stout heavy spines on elevated bases. Ratio length/width of all femora $=5$. Ratios length of foreleg segments: femur 1: tibia 1: tarsus 0.6 (claw not included). Ratio length of hind leg segments: femur 1: tibia 1: tarsus 0.5 . Hind femur is slightly longer than forefemur (1.1 times its length). Forefemur with strong apicomedial indentation (Fig. 12); middle and hind femora with shallower indentation, but apical outer corner more protruded (Figs. 19 and 20). Femoral spines (chalazae) are very short and stout, each one arising from a protruding base ("elevated socket", detail in Fig. 19). Dorsum of all femora is with few spines on mediolongitudinal row, without transversal rows of spines. Fore tarsal claws (Fig. 13) with 12 marginal denticles, without submarginal denticles near apex (only a pair of tiny setae on this area, one at each side); middle and hind tarsal claw similar but with more denticles, from 14 to 17. Abdomen (Figs. 1, 11 and 22-24). Segments I-VII wide, laterally expanded, segments VIII-X thinner. Terga III-VII laterally concave forming a partially closed gill chamber; all segments ending in pointed posterolateral projections (except segment X), longer in VIII-IX. Large median tubercles on all terga except on Xth. Sternum IX with broadly concave apex (female, Fig. 2) or strong subquadrate indentation (male, Fig. 3). Gills present on segments II-VI, operculate gills (Figs. 4 and 5) subquadrate to subovate and with single ventral lamella; gills III-V (Figs. 6-8) subovate with three lamellae, the largest with a small rounded extension at the base; gill VI (Fig. 9) small and rounded formed by two lamellae, the largest with a rounded basal extension. Gill formula 2/3/3/3/2. Cerci slightly longer than terminal filament, with whorls of spines at articulations.

Etymology. Loricyphes from the Latin word loricam meaning breastplate, because of the extremely hardened body cuticle and spine armature, and a reduction of the suffix "hyphes" commonly used in other generic names of the family.

Distribution: Brazil, São Paulo (only known from the type locality).

Loricyphes froehlichi sp. nov.

Diagnosis: see generic section above.

Material: Holotype male nymph from Brazil, State of São Paulo, São Luiz do Paraitinga, rio Paraibuna, Parque Estadual da Serra do Mar (PESM), núcleo Santa Virgínia, $23^{\circ} 20.718^{\prime} \mathrm{S}-45^{\circ} 09.401^{\prime} \mathrm{W}$, 02.viii.09, M. Kuhlmann col. Paratypes: 3 nymphs (parts of a female mature nymph on slide IBN650CM), same data. Holotype and 1 paratype nymph in MZUESC, 2 paratype nymphs at IBN.

Nymph: general color dark brown (female, Figs. 21-23) to yellowish brown (male and immature females, Fig. 24), with blackish markings. Femora grayish yellow, with subapical brownish mark and dark spots around each spine; tibia yellowish to grayish translucent, rest whitish translucent, except apex of claw yellowish. Abdomen ventrally with a mediolongitudinal band darker than the rest. Gill II with operculate portion whitish translucent with dark grayish irregular marks on basal half.

Etymology. This species is dedicated to Dr Claudio G. Froehlich, professor, adviser and friend, for his important contribution to our knowledge of Brazilian aquatic insects, in the year of his academic retirement.

\section{Discussion}

Loricyphes gen. nov., besides the combination of characters mentioned in the diagnosis, present the following unique structures: leg setation (absence of transverse rows of spines on femora, but with a pair of rows formed by chalazae), ridge on outer margin of mandibles, a bifid tubercle on head, two longitudinally arranged tubercles on pro- and mesonotum and the particular morphology of the abdomen (with dorsal tubercles and laterally expanded segments II-VII). The general aspect of the nymph is very similar to Coryphorus aquilus (Coryphoridae), sharing body form, long legs, gill chamber and tubercles on all tagma, but the structure details differ significantly, clearly indicating that the new genus belongs to Leptohyphidae. Transverse row of setae in femora (median or subdistal in foreleg, basal in middle and hind legs) are present in all Leptohyphidae genera (with rare cases of reductions in selected species) but also is a character frequently found in many families of the suborder Pannota (Kluge, 2004). The characters that support placement of Loricyphes in Leptohyphidae are: the structure of the gill, with the lamellae attached basally (not imbricated) and the shape of prementum with apically separated glossae and paraglossae (Molineri et al., 2002).

Chalazae are present in some other Leptohyphidae: Epiphrades undatus (Lugo-Ortiz and McCafferty, 1995), Cabecar serratus Baumgardner and Ávila (2006), and some Leptohyphes species (Baumgardner and McCafferty, 2010; Molineri, 2010). Tubercles on head or thorax are present in Tricorythodes bullus Allen (1967), Tricorythodes cristatus Allen (1967) and Tricorythodes chalaza Gonçalves et al. (2010). Few species in Leptohyphes also show tubercles on head, thorax and abdomen (Nascimento et al., 2014). The gill formula $(2 / 3 / 3 / 3 / 2)$, and form and arrangement of the lamellae in the nymph of Loricyphes are similar to Tricorythodes in the broad sense.

The eggs are unique in form, but share the crescentshaped chorionic plates with other genera of the family (Tricorythodes, Leptohyphes, Traverhyphes, Molineri, 
2001, 2006; Molineri et al., 2014). The presence of a polar cap covering the widest apex could not be confirmed with the few available eggs, but the smooth chorion in the area suggest that it was lost during material preparation.

Acknowledgements. We are grateful to Luke Jacobus, Rafael Boldrini and Fred Salles for the comments on the manuscript. Scanning electron microscopy study was carried-on at Centro de Microscopia Eletrônica (CME), UESC, Ilheus-BA, Brazil. To Centro de Companhia de Tecnologia de Saneamento Ambiental (CETESB), specially to Mônica Kuhlmann for the material. The Argentine National Council of Scientific Research (CONICET), and grants PIP 1484, PIP 0330, PICT 1067, Conselho Nacional Científico e Tecnológico (CNPq) are greatly acknowledged.

\section{References}

Allen R.K., 1967. New species of New World Leptohyphinae (Ephemeroptera: Tricorythidae). Can. Entomol., 99, 350-375.

Baumgardner D.E. and Ávila A.S., 2006. Cabecar serratus, a new genus and species of leptohyphid mayfly from Central America, and description of the imaginal stages of Tricorythodes sordidus Allen (Ephemeroptera: Leptohyphidae). Zootaxa, 1187, 47-59.

Baumgardner D.E. and McCafferty W.P., 2010. Revision of the genus Leptohyphes Eaton (Ephemeroptera: Leptohyphidae) in North and Central America. Zootaxa, 2360, 1-33.

Dias L.G., Molineri C. and Ferreira P.S.F., 2007. Ephemerelloidea (Insecta: Ephemeroptera) do Brazil. Pap. Avulsos Zool., 47, 213-244.

Domínguez E., Molineri C., Pescador M., Hubbard M.D. and Nieto C., 2006. Ephemeroptera of South America. In: Adis J. et al. (eds.), Aquatic Biodiversity in Latin America (ABLA), Vol. 2, Pensoft, Sofia-Moscow, 646 p.

Gonçalves I.C., Da-Silva E.R. and Nessimian J.L., 2010. Two new species of Tricorythodes Ulmer, 1920 (Insecta,
Ephemeroptera) from Southeastern Brazil. Zootaxa, 2721, 62-68.

Kluge, N. 2004. The Phylogenetic System of Ephemeroptera, Kluwer Academic Publishers, Dodrecht/Boston/London, $442 \mathrm{p}$.

Lugo-Ortiz C.R. and McCafferty W.P., 1995. Contribution to the taxonomy of the Leptohyphidae (Insecta: Ephemeroptera) of Central America. Stud. Neotrop. Fauna Environ., 30, 165-176.

Molineri C., 2001. Una especie nueva de Tricorythodes (Ephemeroptera: Leptohyphidae) de la Argentina con notas sobre su biología. Rev. Soc. Entomol. Argent., 60, 61-66.

Molineri C., 2002. Cladistic analysis of the South American species of Tricorythodes (Ephemeroptera: Leptohyphidae) with the description of new species and stages. Aquat. Insect, 24, 273-308.

Molineri C., 2006. Phylogeny of the mayfly family Leptohyphidae (Insecta: Ephemeroptera) in South America. Syst. Entomol., 31, 1-18.

Molineri C., 2010. Las especies de Leptohyphidae (Ephemeroptera) de las yungas de Argentina y Bolivia: diagnosis, distribución y claves. Rev. Soc. Entomol. Argent., 69, 233-252.

Molineri C., Peters J.G. and Zúñiga M.C., 2002. A new family, Coryphoridae (Ephemeroptera: Ephemerelloidea), and description of the winged and egg stages of Coryphorus. Insecta Mundi, 15, 117-122.

Molineri C., Grillet M.E. and Guerrero E., 2014. Tricorythodes faeculopsis (Ephemeroptera: Leptohyphidae), description of new stages and first record from Venezuela. Rev. Soc. Entomol. Argent., 73, 91-97.

Nascimento J.M.C., Molineri C. and Salles F.F., 2014. Redescription of Leptohyphes cornutus Allen, 1967 (Ephemeroptera: Leptohyphidae) and description of three related new species. Zootaxa, 3893, 397-415.

Wiersema N.A. and McCafferty W.P., 2000. Generic revision of the North and Central American Leptohyphidae (Ephemeroptera: Pannota). Trans. Am. Entomol. Soc., 126, 337-371. 